\title{
SINTERING OF OXYGEN ION CONDUCTIVE CERAMICS AND THEIR ELECTRICAL PROPERTIES
}

\author{
S. Kazlauskas, A. Kežionis, T. Šalkus, and A.F. Orliukas \\ Faculty of Physics, Vilnius University, Sauletekio 9, LT-10222 Vilnius, Lithuania \\ E-mail: saulius.kazlauskas@ff.vu.lt
}

Received 24 February 2012; revised 24 April 2012; accepted 20 September 2012

\begin{abstract}
Oxygen ion conducting ceramics $\left(\mathrm{Sc}_{2} \mathrm{O}_{3}\right)_{0.1}\left(\mathrm{ZrO}_{2}\right)_{0.9},\left(\mathrm{Sc}_{2} \mathrm{O}_{3}\right)_{0.1}\left(\mathrm{CeO}_{2}\right)_{0.01}\left(\mathrm{ZrO}_{2}\right)_{0.89}$ and $\mathrm{Ce}_{0.9} \mathrm{Gd}_{0.1} \mathrm{O}_{1.95}$ were sintered from powders with different specific surface areas. The produced ceramics were studied by scanning electron microscopy and impedance spectroscopy methods. Impedance spectroscopy measurements were performed in a wide frequency range of $10 \mathrm{~Hz}-3 \mathrm{GHz}$ at temperatures up to $900 \mathrm{~K}$ in air. Temperature dependences of bulk and total ionic conductivities of ceramics were investigated. High bulk ionic conductivity of the order of $1 \mathrm{~S} / \mathrm{m}$ at $900 \mathrm{~K}$ for $10 \mathrm{ScSZ}$ and $10 \mathrm{Sc1CeSZ}$ ceramics was achieved. Total ionic conductivity for both types of $10 \mathrm{GDC}$ ceramics was of the order of $0.1 \mathrm{~S} / \mathrm{m}$ at $700 \mathrm{~K}$.
\end{abstract}

Keywords: solid electrolyte, ionic conductivity, ScSZ, GDC

PACS: 81.05.Je, 66.30.Dn

\section{Introduction}

Challenges exist in the solid oxide fuel cell (SOFC) research area due to their high operating temperatures, which results in the degradation of SOFC components, material compatibility issues and etc.

The yttria-stabilised zirconia (YSZ) electrolyte is the most common material employed as an electrolyte in SOFCs. However, high temperatures in the range of $1070-1270 \mathrm{~K}$ are required to obtain sufficient ionic conductivity (approximately $1 \mathrm{~S} / \mathrm{m}$ ) in YSZ for SOFC operation [1]. Therefore, materials which exhibit sufficient ionic conductivity at lower temperatures have attracted great attention of scientists worldwide.

Zirconia remains a prime choice as an electrolyte material because of its stability and compatibility with the electrode materials over wide ranges of temperatures. Ionic conductivity of stabilised zirconia depends on the size of dopant cations and tends to be the highest for those with ionic radii close to that of the host $\mathrm{Zr}^{4+}(0.84 \AA)$ [2]. In the case of zirconia-based systems, $\mathrm{Sc}^{3+}$ with radii of $0.87 \AA$ should be the most effective dopant among $\mathrm{Ca}^{2+}$, $\mathrm{Y}^{3+}, \mathrm{Sm}^{3+}$, etc. Scandia-stabilised zirconia (ScSZ) is a promising material: for example, $11 \mathrm{~mol} \%$ $\mathrm{Sc}_{2} \mathrm{O}_{3}-\mathrm{ZrO}_{2}$ ceramic (11ScSZ) exhibits sufficient ionic conductivity for SOFC operation at $870 \mathrm{~K}$ [ [3].

However, ScSZ (9-13 mol\% $\mathrm{Sc}_{2} \mathrm{O}_{3}$ ) suffers a phase transition to the rhombohedral phase around $800-900 \mathrm{~K}$ (depending on dopant amount), which is unique for Sc-stabilised zirconias [4]. The thermocycling process of such material eventually leads to a reduced ionic conductivity and material degradation. There are reports in literature that the stabilisation of the cubic phase ScSZ in lower temperatures can be achieved by co-doping with small amounts (0.5-1.5 mol\%) of other oxides $\left(\mathrm{Gd}_{2} \mathrm{O}_{3}\right.$, $\mathrm{Y}_{2} \mathrm{O}_{3}, \mathrm{Bi}_{2} \mathrm{O}_{3}$, or $\mathrm{CeO}_{2}$ ) [5]. However, the effect of various ternary dopants on this process has not been studied in detail.

In recent years many other systems, such as various ceria-based oxides, have also been proposed as electrolyte material for SOFC. Regarding doped zirconia, one of the best dopants due to its optimum atomic radius are $\mathrm{Y}^{3+}(1.019 \AA)$, or $\mathrm{Gd}^{3+}(1.053 \AA)$. 
However, there is still discrepancy in understanding the relationship between the dopant properties and the ionic conductivity: gadolinium doped ceria have higher ionic conductivity than yttrium doped ceria [6], although the best match for the ionic radius of $\mathrm{Ce}^{4+}(0.97 \AA)$ is yttrium. Gadolinium doped ceria (GDC) has shown higher ionic conductivity at $870-1070 \mathrm{~K}$ than conventional YSZ [阴, and its conductivity is comparable to the conductivity of ScSZ.

One problem concerning ceria-based electrolytes is that conventional sintering to full density requires temperatures exceeding $1570 \mathrm{~K}$ [8]. Rather high grain growth rates at those temperatures result in large grains and therefore poor mechanical stability. In order to obtain ceramics with small grains and high stability, powders with a high surface area should be used for sintering.

In this paper we present sintering conditions and electrical properties in a wide frequency and temperature range of $10 \mathrm{GDC}, 10 \mathrm{ScSZ}$, and $10 \mathrm{Sc1CeSZ}$ ceramics. Sintered ceramics were studied by scanning electron microscopy (SEM) and impedance spectroscopy (IS) methods in a wide frequency range $10 \mathrm{~Hz}-3 \mathrm{GHz}$ at temperatures up to $900 \mathrm{~K}$ in air.

\section{Experiment}

Solid electrolyte ceramics were sintered from commercial powders $\left(\mathrm{Sc}_{2} \mathrm{O}_{3}\right)_{0.1}\left(\mathrm{ZrO}_{2}\right)_{0.9}(10 \mathrm{ScSZ})$, $\left(\mathrm{Sc}_{2} \mathrm{O}_{3}\right)_{0.1}\left(\mathrm{CeO}_{2}\right)_{0.01}\left(\mathrm{ZrO}_{2}\right)_{0.89} \quad(10 \mathrm{Sc} 1 \mathrm{CeSZ})$, and $\mathrm{Ce}_{0.9} \mathrm{Gd}_{0.1} \mathrm{O}_{1.95}$ (10GDC) produced by Fuel Cell Materials. For preparing 10GDC ceramics two types of the powders with different surface areas $S_{\text {BET }}=6.44 \mathrm{~m}^{2} / \mathrm{g}$ and $S_{\text {BET }}=201 \mathrm{~m}^{2} / \mathrm{g}$ were used. Powders were shaped by uniaxial cold pressing at $300 \mathrm{MPa}$. Ceramics were sintered in air atmosphere for $1 \mathrm{~h}$, sintering temperatures of ScSZ and 10GDC ceramics were 1773 and $1673 \mathrm{~K}$, respectively. The surfaces of ceramic samples were observed by a scanning electron microscope in the secondary electron mode. This study allows one to determine the qualitative distribution of grains and grain boundaries and to compare the microstructure of ceramics sintered using different powders.

For the measurements of complex specific ionic conductivity $(\widetilde{\sigma})$ and complex specific impedance $(\widetilde{\rho})$ in a low frequency range (from $10 \mathrm{~Hz}$ to $2 \mathrm{MHz}$ ) 2 -electrode and 4-electrode methods were used [9].
Corresponding investigations in a high frequency range (from $0.3 \mathrm{MHz}$ to $3 \mathrm{GHz}$ ) were based on the measurement of the $S$-parameters matrix for a 2-port network made of a coaxial waveguide and a sample inserted in the gap of the central conductor [10]. For 2-electrode and high frequency measurement techniques cylindrical samples of the height of $1.5 \mathrm{~mm}$ and of the diameter of $2.5 \mathrm{~mm}$ were prepared from sintered ceramics; for the 4-electrode method rectangular samples $(8 \times 1.5 \times 1.5 \mathrm{~mm})$ were used. The electrodes of the samples were prepared using Pt paste, except for voltage electrodes in case of the 4-electrode method: platinum wires wound around the sample were used. All measurements were carried out in air, and temperature was controlled by a computer connected to DC power supply.

The spectra of measured electrical properties were analysed by means of nonlinear least-squares fitting of equivalent circuit (Fig.11) with the aid of the Zview program. All the capacitances shown in the equivalent electrical circuit were mathematically modelled using a constant phase element (CPE) [11].

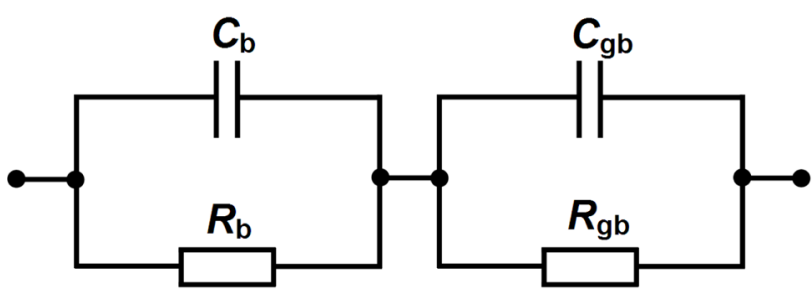

Fig. 1. Equivalent circuit comprising two parallel $R$ and $C$ circuits in series.

\section{Results and discussion}

The most important parameters of sintered ceramics are summarised in Table 1 . The $S_{\mathrm{BET}}$ represents the surface area of the powder $\left(\mathrm{m}^{2} / \mathrm{g}\right)$ determined using the BET (Brunauer, Emmett \& Teller) method.

SEM images of surfaces of $10 \mathrm{ScSZ}$ and 10Sc1CeSZceramics are shown in Fig. 2. No significant differences can be seen in the microstructure of the samples: grain size varies from about 1 to $12 \mu \mathrm{m}$ in both samples. The microstructure of 10GDC ceramics is shown in Fig. 3. The grain sizes of these ceramics are similar, there is no expected 
Table 1. Surface areas, sintering temperatures and densities of investigated ceramics.

\begin{tabular}{c|c|c|c|c|c}
\hline Compound & $\begin{array}{c}\text { Powder } \\
\text { surface area } \\
S_{\mathrm{BET}}\left[\mathrm{m}^{2} / \mathrm{g}\right]\end{array}$ & $\begin{array}{c}\text { Sintering } \\
\text { temperature } \\
T_{\text {sint }}[\mathrm{K}]\end{array}$ & $\begin{array}{c}\text { Actual den- } \\
\text { sity } \rho_{\mathrm{a}} \\
{\left[\mathrm{g} / \mathrm{cm}^{3}\right]}\end{array}$ & $\begin{array}{c}\text { Relative } \\
\text { density }[\%]\end{array}$ & $\begin{array}{c}\text { Theoretical } \\
\text { density } \rho_{\mathrm{t}} \\
{\left[\mathrm{g} / \mathrm{cm}^{3}\right]}\end{array}$ \\
\hline$\left(\mathrm{Sc}_{2} \mathrm{O}_{3}\right)_{0.1}\left(\mathrm{ZrO}_{2}\right)_{0.9}$ & 11.1 & 1773 & 5.35 & 94.1 & $5.68[12]$ \\
\hline$\left(\mathrm{Sc}_{2} \mathrm{O}_{3}\right)_{0.1}\left(\mathrm{CeO}_{2}\right)_{0.01}\left(\mathrm{ZrO}_{2}\right)_{0.89}$ & 9.4 & 1773 & 5.48 & 95.4 & $5.74[12]$ \\
\hline $\mathrm{Ce}_{0.9} \mathrm{Gd}_{0.1} \mathrm{O}_{1.95}$ & 6.44 & 1673 & 6.93 & 96.1 & $7.21[13]$ \\
\hline $\mathrm{Ce}_{0.9} \mathrm{Gd}_{0.1} \mathrm{O}_{1.95}$ & 201 & 1673 & 6.99 & 96.9 & $7.21[13]$ \\
\hline
\end{tabular}
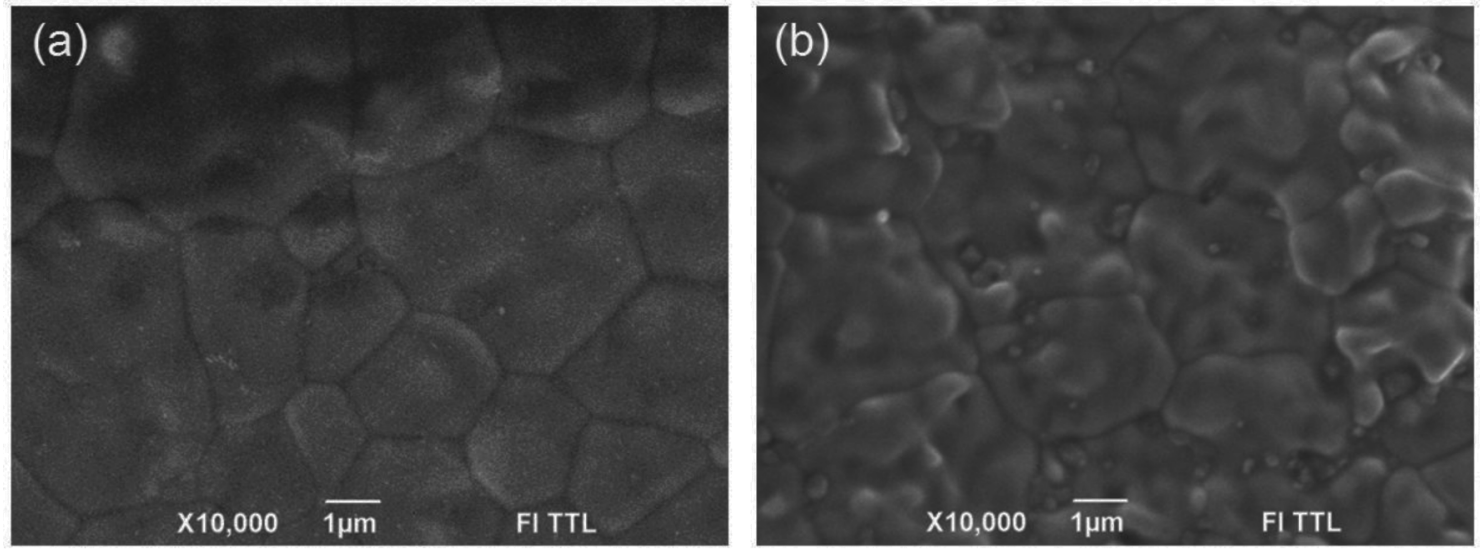

Fig. 2. SEM images of surfaces of (a) $10 \mathrm{Sc} 1 \mathrm{CeSZ}$ and (b) $10 \mathrm{ScSZ}$ ceramics.
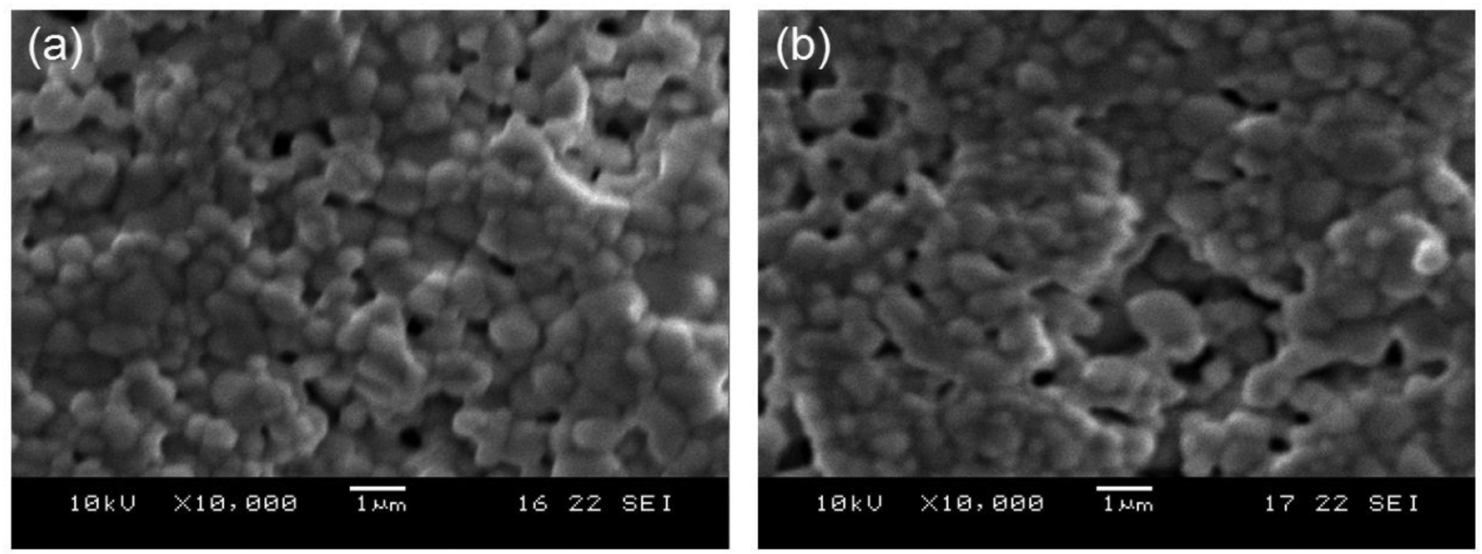

Fig. 3. SEM images of surfaces of (a) $10 \mathrm{GDC}_{S=6.44}$ and (b) $10 \mathrm{GDC}_{S=201}$ ceramics.

difference resulting from the distinct surface area of powders of which ceramics were sintered. Both 10GDC ceramics were sintered at the same temperature ( $T=1673 \mathrm{~K})$, the sintering time was equal; these factors could make a crucial influence on microstructure. The experimentally measured ionic conductivity dependences of 10GDC ceramics are overlapped in Figs. 4, 8, 9 due to identical stoichiometric composition and very similar microstructure.
The frequency dependences of the real part $\sigma^{\prime}$ of complex ionic conductivity $(\widetilde{\sigma})$ of investigated ceramics are presented in Fig. 4. Two relaxation dispersions have been found in ionic conductivity and impedance spectra of the studied ceramics. Considering literature data [14, 15, dispersion in a high frequency region (I) was attributed to oxygen ion relaxation in the bulk. Whereas minor dispersion in intermediate and low frequency ranges (II) 


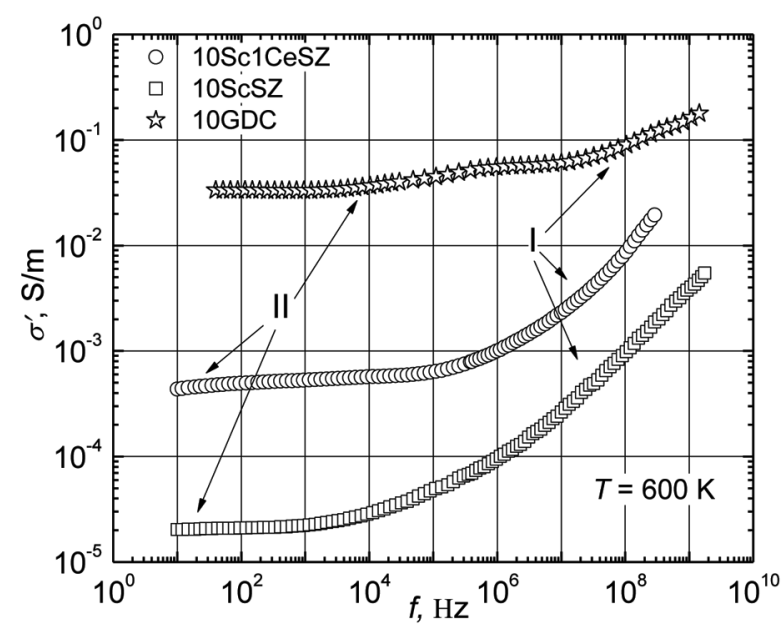

Fig. 4. Frequency dependences of the real part of conductivity of 10ScSZ, 10Sc1CeSZ, and both 10GDC (overlapped) ceramics.

was caused by the ion blocking effect at the grain boundaries of the ceramics.

Bulk and total ionic conductivities were derived from complex specific impedance $\rho^{\prime}=f\left(\rho^{\prime}\right)$ plots at different temperatures using a detailed analysis of the data points. Bulk ionic conductivity $\sigma_{\mathrm{b}}=1 / \rho_{\mathrm{b}}$ ( $\rho_{\mathrm{b}}$ bulk specific resistance) is a material-specific constant, which approximately corresponds to dc ionic conductivity of the single crystal of a given compound. Total ionic conductivity $\sigma_{\mathrm{t}}=1 / \rho_{\mathrm{t}}$ ( $\rho_{\mathrm{t}}$ total specific resistance) is a similar material-specific constant, which corresponds to dc ionic conductivity of a given polycrystalline compound.

As an example, the specific impedance of 10GDC ceramics measured at $580 \mathrm{~K}$ is shown in a complex plane in Fig. 5, where parameter $f$ indicates average ion relaxation frequencies in the bulk and the grain boundary. Using an equivalent circuit tech-

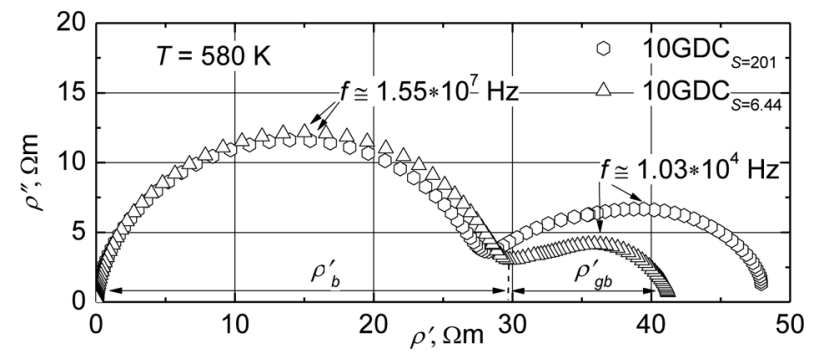

Fig. 5. Complex plane plots of specific impedance of $10 \mathrm{GDC}_{s=6.44}$ and $10 \mathrm{GDC}_{s=201}$ ceramics. nique frequently used in the literature [14, 15], the semicircle at higher frequencies (on the left-hand side of the spectrum) corresponds to bulk specific resistance $\rho_{\mathrm{b}}$ and the one at lower frequencies (on the right-hand side of the spectrum) corresponds to the resistance of grain boundaries of the ceramic $\rho_{\mathrm{gb}}$. Total specific resistance is the sum of bulk and grain boundary resistances: $\rho_{\mathrm{t}}=\rho_{\mathrm{b}}+\rho_{\mathrm{gb}}$. By using the 4-electrodes technique impedance measuring methods, the interface Pt-electrolyte, which relatively blocks the ionic current, was eliminated from the electrochemical system and the third semicircle does not appear in the impedance spectra.

Specific impedance in the complex plane of $10 \mathrm{Sc} 1 \mathrm{CeSZ}$ and $10 \mathrm{ScSZ}$ ceramics measured at 580 and $620 \mathrm{~K}$, respectively, using the 2-electrode method is shown in Fig. 6. These diagrams show only one semicircle, which defines bulk ionic conductivity. An examination of the data points on the low frequency side shows deviation from semicircle, and precise separation between the grain boundary and electrode characteristic could not be distinguished. For these temperatures (and all temperatures below $820 \mathrm{~K}$, the range wherein the phase of $10 \mathrm{ScSZ}$ is rhombohedral), the bulk ionic conductivity of $10 \mathrm{Sc} 1 \mathrm{CeSZ}$ is ten or more times higher than that of $10 \mathrm{ScSZ}$.

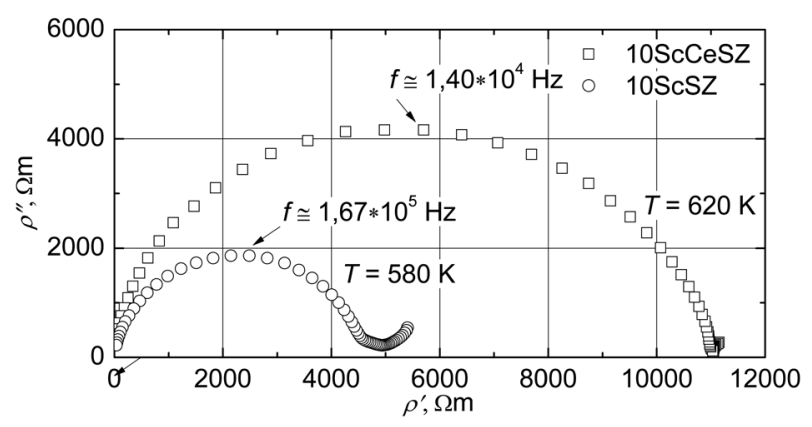

Fig. 6. Complex plane plots of specific impedance of $10 \mathrm{Sc} 1 \mathrm{CeSZ}$ and $10 \mathrm{ScSZ}$ ceramics.

As mentioned before, the practical use of ScSZ (9-13 mol\%) ceramics is hindered by phase transition at high temperatures. The investigated $10 \mathrm{ScSZ}$ ceramic sample suffers phase transition to the rhombohedral phase at around $820 \mathrm{~K}$, leading to 
increased ionic conductivity. This phase transition was suppressed using co-doping with $1 \mathrm{~mol} \%$ of cerium oxide. The bulk ionic conductivities of $10 \mathrm{ScSZ}$ and $10 \mathrm{Sc1CeSZ}$ ceramics at temperatures above $820 \mathrm{~K}$ are very similar (Fig. 7).

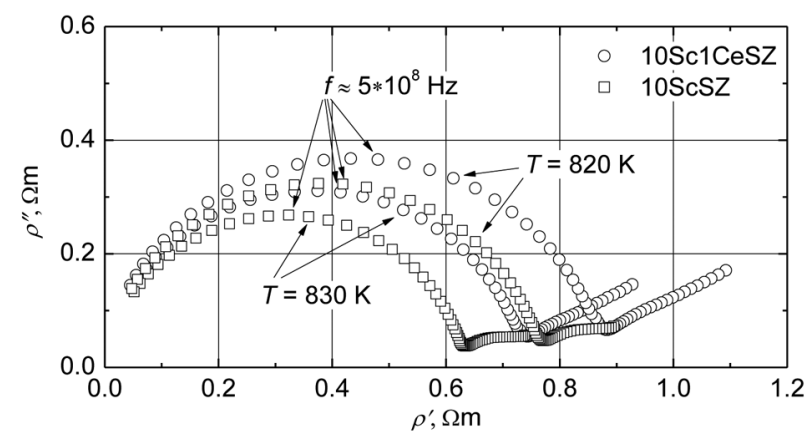

Fig. 7. Complex plane plots of specific impedance of $10 \mathrm{Sc} 1 \mathrm{CeSZ}$ and $10 \mathrm{ScSZ}$ ceramics.

Temperature dependences of $\sigma_{\mathrm{b}}$ and $\sigma_{\mathrm{t}}$ of investigated ceramics are shown in Arrhenius plots (Figs. 8 and 9, respectively). When comparing the individual plots (Fig.8) it is remarkable that the bulk ionic conductivity of $10 \mathrm{ScSZ}$ increases very rapidly in the region of phase transition. $10 \mathrm{SclCeSZ}$ and 10ScSZ ceramics exhibit 3.4 and $3.7 \mathrm{~S} / \mathrm{m}$ bulk ionic conductivity at $900 \mathrm{~K}$. Bulk ionic conductivity of 10GDC ceramics achieves $0.32 \mathrm{~S} / \mathrm{m}$ at $700 \mathrm{~K}$.

The total ionic conductivity of $10 \mathrm{Sc} 1 \mathrm{CeSZ}$ was measured using the 4-electrode technique. 10ScSZ possess phase transition, which limits its use as a SOFC electrolyte and therefore the total conductivity of this material has no meaning. The total ionic conductivity of $10 \mathrm{Sc} 1 \mathrm{CeSZ}$ ceramic is $0.05 \mathrm{~S} / \mathrm{m}$ at $700 \mathrm{~K} .10 \mathrm{GDC}$ ceramics shows a $0.26 \mathrm{~S} / \mathrm{m}$ total ionic conductivity at the same temperature.

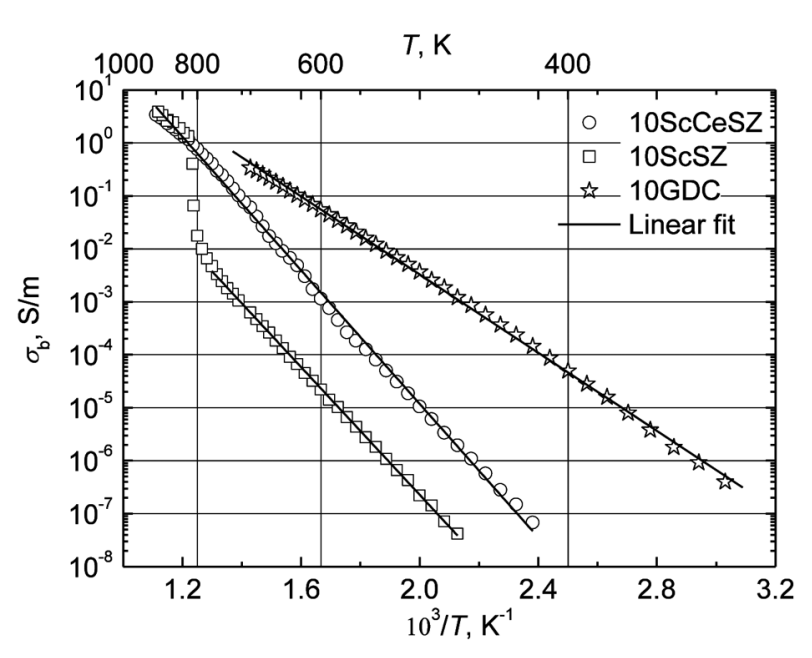

Fig. 8. Temperature dependences of bulk conductivities of $10 \mathrm{ScSZ}, 10 \mathrm{Sc} 1 \mathrm{CeSZ}$, and both 10GDC (overlapped) ceramics.

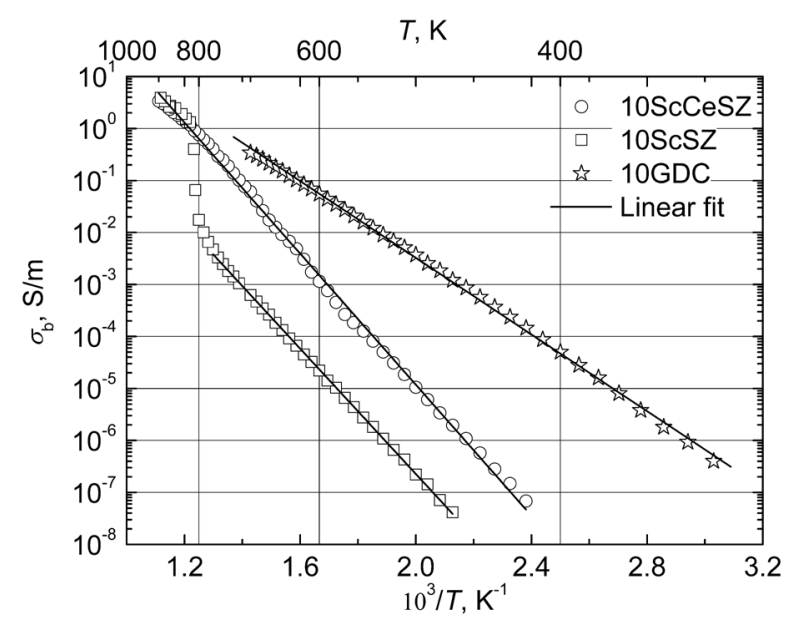

Fig. 9. Temperature dependences of the total conductivities of 10Sc1CeSZ and both 10GDC (overlapped) ceramics.

The corresponding activation energies (determined from the Arrhenius plots shown in Figs. 8 and 9) are very close. The activation energies $E_{\mathrm{b}}, E_{\mathrm{t}}$ and $\sigma_{\mathrm{b}}, \sigma_{\mathrm{t}}$ conductivities at different temperatures are summarised in Table 2 .

Table 2. Activation energies and conductivities at different temperatures of investigated ceramics.

\begin{tabular}{c|c|c|c|c|c|c|c}
\hline Compound & $\begin{array}{c}\text { Activation } \\
\text { energy } \\
\Delta E_{\mathrm{b}}[\mathrm{eV}]\end{array}$ & $\begin{array}{c}\text { Activation } \\
\text { energy } \Delta E_{\mathrm{t}} \\
{[\mathrm{eV}]}\end{array}$ & $\begin{array}{c}\sigma_{\mathrm{b}}[\mathrm{S} / \mathrm{m}] \\
\text { at } 500 \mathrm{~K}\end{array}$ & $\begin{array}{c}\sigma_{\mathrm{b}}[\mathrm{S} / \mathrm{m}] \\
\text { at } 700 \mathrm{~K}\end{array}$ & $\begin{array}{c}\sigma_{\mathrm{b}}[\mathrm{S} / \mathrm{m}] \\
\text { at } 900 \mathrm{~K}\end{array}$ & $\begin{array}{c}\sigma_{\mathrm{t}}[\mathrm{S} / \mathrm{m}] \\
\text { at } 500 \mathrm{~K}\end{array}$ & $\begin{array}{c}\sigma_{\mathrm{t}}[\mathrm{S} / \mathrm{m}] \\
\text { at } 700 \mathrm{~K}\end{array}$ \\
\hline$\left(\mathrm{Sc}_{2} \mathrm{O}_{3}\right)_{0.1}\left(\mathrm{ZrO}_{2}\right)_{0.9}$ & 1.07 & - & $2.3 \cdot 10^{-7}$ & $6.3 \cdot 10^{-4}$ & 3.9 & - & - \\
\hline$\left(\mathrm{Sc}_{2} \mathrm{O}_{3}\right)_{0.1}\left(\mathrm{CeO}_{2}\right)_{0.01}\left(\mathrm{ZrO}_{2}\right)_{0.89}$ & 1.55 & 1.33 & $1.0 \cdot 10^{-5}$ & $6.1 \cdot 10^{-2}$ & 3.4 & $6.0 \cdot 10^{-6}$ & $5.0 \cdot 10^{-2}$ \\
\hline $\mathrm{Ce}_{0.9} \mathrm{Gd}_{0.1} \mathrm{O}_{1.95(S=6.44)}$ & 0.96 & 1.01 & $3.7 \cdot 10^{-3}$ & $3.2 \cdot 10^{-1}$ & - & $2.5 \cdot 10^{-3}$ & $2.6 \cdot 10^{-1}$ \\
\hline $\mathrm{Ce}_{0.9} \mathrm{Gd}_{0.1} \mathrm{O}_{1.95(S=201)}$ & 0.97 & 0.98 & $3.6 \cdot 10^{-3}$ & $3.3 \cdot 10^{-1}$ & - & $2.3 \cdot 10^{-3}$ & $2.7 \cdot 10^{-1}$ \\
\hline
\end{tabular}




\section{Conclusions}

The ceramic compounds $10 \mathrm{ScSZ}, 10 \mathrm{Sc} 1 \mathrm{CeSZ}$, and $10 \mathrm{GDC}$ were sintered and relative density greater than $94 \%$ was achieved.

Two different scandium-doped zirconia systems with composition 10ScSZ and 10Sc1CeSZ were studied with a particular interest to the effect of ternary dopant on electrical properties. An addition of $1 \mathrm{~mol} \% \mathrm{CeO}_{2}$ significantly decreases the phase transition temperature and stabilises the cubic phase. The IS study of the ceramics has revealed that both scandium-based ceramics exhibit the bulk ionic conductivity of the order of $1 \mathrm{~S} / \mathrm{m}$ at $900 \mathrm{~K}$. The total ionic conductivity of $10 \mathrm{Sc1CeSZ}$ reaches $0.01 \mathrm{~S} / \mathrm{m}$ at $700 \mathrm{~K}$.

The images of 10GDC ceramics did not show any expected difference of the microstructure for sintered ceramics from different powder. High sintering temperature allowed fast crystal growth and the difference of the specific surface area of powders has no impact on bulk and total ionic conductivities and their activation energies. However, bulk and total ionic conductivities of both 10GDC ceramics are in the order of $0.1 \mathrm{~S} / \mathrm{m}$ at $700 \mathrm{~K}$.

All investigated ceramics (except for 10ScSZ) showed results which are appropriate for successful operation as an electrolyte in intermediate temperature SOFCs.

\section{Acknowledgements}

This work was supported by Research Council of Lithuania project No.ATE-09/2012.

\section{References}

[1] B.C.H. Steele and A. Heinzel, Materials for fuelcell technologies, Nature 414, 345-352 (2001).

[2] D.W. Strickler and W.G. Carlson, Electrical conductivity in the $\mathrm{ZrO}_{2}$-rich region of several $\mathrm{M}_{2} \mathrm{O}_{3}-$ $\mathrm{ZrO}_{2}$ systems, J. Am. Ceram. Soc. 48(6), 286-289 (1965).
[3] S.P.S. Badwal and F.T. Ciacchi, Oxygen-ion conducting electrolyte materials for solid oxide fuel cells, Ionics 6, 1-21 (2000).

[4] R. Ruh, H.J. Garrett, R.F. Domagala, and V.A. Patel, The system zirconia-scandia, J. Am. Ceram. Soc. 60(9), 399-403 (1977).

[5] O. Yamamoto, Y. Arati, Y. Takeda, N. Imanishi, Y. Mitzutani, and M. Kawai, Electrical conductivity of stabilized zirconia with ytterbia and scandia, Solid State Ionics 79(2), 137-142 (1995).

[6] H. Inaba and H. Tagawab, Ceria-based solid electrolytes, Solid State Ionics 83(1), 1-16 (1996).

[7] M. Mogensen, N.M. Sammes, and G.A. Tompsett, Physical, chemical and electrochemical properties of pure and doped ceria, Solid State Ionics 129, 63-94 (2000).

[8] Y.C. Zhou, R.J. Philips, and J.A. Switzer, Electrochemical synthesis and sintering of nanocrystalline cerium(IV) oxide powders, J. Am. Ceram. Soc. 78(4), 981-985 (1995).

[9] A. Kežionis, E. Kazakevičius, T. Šalkus, and A.F. Orliukas, All-purpose impedance spectrometer, in: Programme and Book of Abstracts: Lithuanian-French-Ukrainian Workshop on Materials for Functional Elements of Solid State Ionics (Vilnius, 2008).

[10]A. Kežionis, E. Kazakevičius, T. Šalkus, and A.F. Orliukas, Broadband high frequency impedance spectrometer with working temperatures up to $1200 \mathrm{~K}$, Solid State Ionics 188(1), 110-113 (2011).

[11]J. Fleig, The grain boundary impedance of random microstructures: numerical simulations and implications for the analysis of experimental data, Solid State Ionics 150(1), 181-193 (2002).

[12] C. Suciu, E.S. Erichsen, and A.C. Hoffmann, Modified sol-gel method used for obtaining SOFC electrolyte materials, ECS Trans. 25(2), 1679-1686 (2009).

[13]K. Huang, M. Feng, and J.B. Goodenough, Synthesis and electrical properties of dense $\mathrm{Ce}_{0.9} \mathrm{Gd}_{0.1} \mathrm{O}_{1.95}$ ceramics, J. Am. Ceram. Soc. 81(2), 357-362 (1998).

[14] J.E. Bauerle, Study of solid electrolyte polarization by a complex admittance method, J. Phys. Chem. Solids 30, 2657-2670 (1969).

[15]J.R. Macdonald and J.A. Garber, Analysis of impedance and admittance data for solids and liquids, J. Electrochem. Soc. 124, 1022-1030 (1977). 


\title{
DEGUONIES JONAMS LAIDŽIŲJŲ KERAMIKŲ KEPINIMAS IR JŲ ELEKTRINĖS
} SAVYBĖS

\author{
S. Kazlauskas, A. Kežionis, T. Šalkus, A. F. Orliukas \\ Vilniaus universiteto Fizikos fakultetas, Vilnius, Lietuva
}

\section{Santrauka}

Iš $\left(\mathrm{Sc}_{2} \mathrm{O}_{3}\right)_{0,1}\left(\mathrm{ZrO}_{2}\right)_{0,9}(10 \mathrm{ScSZ}),\left(\mathrm{Sc}_{2} \mathrm{O}_{3}\right)_{0,1}\left(\mathrm{CeO}_{2}\right)_{0,01 \text { - }}$ $\left(\mathrm{ZrO}_{2}\right)_{0,89}(10 \mathrm{Sc} 1 \mathrm{CeSZ})$ ir $\mathrm{Ce}_{0,9} \mathrm{Gd}_{0,1} \mathrm{O}_{1,95}(10 \mathrm{GDC})$ miltelių, kurių savitasis paviršiaus plotas $S=6,44$ ir $201 \mathrm{~m}^{2} / \mathrm{g}$, buvo pagamintos deguonies jonams laidžiosios keramikos. Siekiant nustatyti keramikų gamybos technologinių sąlygų ittaką jų mikrostruktūrai, keramikų paviršiai buvo ištirti skenuojančiu elektroniniu mikroskopu (SEM). Elektrinès šių keramikų savybès buvo tiriamos plačiame dažnių (10 Hz-3 GHz) ir temperatūrų (300-900 K) diapazone pilnutinès varžos spektroskopijos (IS) metodais.

Iš SEM nuotraukų nustatyta, jog kristalitų dydžiai keramikose $10 \mathrm{ScSZ}$ ir $10 \mathrm{Sc} 1 \mathrm{CeSZ}$ yra panašūs, jie kinta nuo $1 \mathrm{iki} 12 \mu \mathrm{m}$. Iš skirtingo paviršiaus ploto miltelių pagamintų 10GDC keramikų kristalitų dydžiai taip pat labai artimi, tačiau jie keletą kartų mažesni nei cirkonio keramikų. Naudojantis IS rezultatais, buvo įvertinti kris- talitinis $\sigma_{\mathrm{b}}$ ir bendrasis $\sigma_{\mathrm{t}}$ keramikų laidumai. Keičiant temperatūrą, šie dydžiai kinta pagal Arenijaus dèsnị.

Staigus kristalitinio laidumo padidèjimas, stebimas $820 \mathrm{~K}$ temperatūroje $10 \mathrm{~mol} \%$ skandžiu stabilizuoto cirkonio oksido (10ScSZ) keramikoje, yra susijęs su $10 S c S Z$ struktūriniu faziniu virsmu. Junginyje, kuriame i $10 \mathrm{ScSZ}$ buvo ịvesta $1 \mathrm{~mol} \% \mathrm{CeO}_{2}$ priemaišų, 300$850 \mathrm{~K}$ temperatūrų intervale laidumo šuolis nestebimas.

10Sc1CeSZ ir 10ScSZ keramiku kristalitinis laidumas yra didesnis nei $2 \mathrm{~S} / \mathrm{m}$ esant $900 \mathrm{~K}$ temperatūrai, o abiejų 10GDC keramikų bendrasis laidumas buvo jau $0,1 \mathrm{~S} / \mathrm{m}$ esant $700 \mathrm{~K}$ temperatūrai.

Visų tyrinètų keramikų (išskyrus 10ScSZ) rezultatai rodo, jog jos pasižymi dideliu joniniu laidumu ir atitinka reikalavimus, keliamus vidutinių temperatūrų kietojo kuro gardelèms (SOFC). 